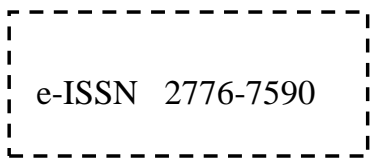

Vol. 2, No. 1, pp. 43-48, 2022

\title{
Strengthening School Counseling Guidance Activities Through e-Counseling
}

\author{
Prihastuti Harsani ${ }^{1 *}$, Erniyati ${ }^{2}$, Dadang Kurnia ${ }^{3}$ \\ 1,2, 3 Universitas Pakuan affiliation, Bogor, Indonesia \\ *Corresponding author email: prihastuti.harsani@unpak.ac.id
}

\begin{abstract}
Cybercounseling is defined as a professional counseling practice that occurs when the counselee and counselor are separately and utilize electronic media to communicate via the internet. Several problems arise in student coaching activities by Guidance Counseling teachers, namely: not yet optimal use of cyber counseling applications, recording of student progress, which is still done manually, and the unavailability of facilities for students to express academic and non-academic problems. The technology provided is an e-counseling application. The method used in this activity is an e-counseling implementation workshop. Computer Vocational Schools as partners have been involved in the stages of needs identification, implementation, and trials. The school elements involved are Principals, Students, BK teachers, and homeroom teachers. This technology provides an alternative repository of student development. Based on the results of the workshop, it was found that the repository was available at $85 \%$ and the usability level of the system was $75 \%$.
\end{abstract}

Keywords: school, students, counseling guidance, repository.

\section{Introduction}

Online counseling first appeared in the 1960s and 1970s with the software program Eliza and Parry, in the early development of online counseling it was text-based, and now about a third of sites offer counseling only via e-mail (Shaw \& Shaw in Koutsonika, 2009). In 1999, ISMHO established the Online Clinical Case Study Group (CSG) consisting of mental health professionals from the fields of psychology, psychiatry, social work, nursing, family therapy, and community counseling (Kraus, 2010).

Online counseling is an alternative effort that can be done by counselors to prevent, reduce, develop an awareness of self-correction, improve and help solve client problems with virtual or internet methods. Online counseling as a step in implementing technology in guidance and counseling services is facing the 4.0 era where it is hoped that in its implementation it is hoped that the ethics in guidance and counseling have been applied. Become a professional online counselor by innovating services according to the demands and needs of the 4.0 era.

Specifically, there are two types of services in counseling via the internet, namely: (1) Non-Interactive; (2) Synchronous Interactive and Asynchronous Interactive (Gumilang, 2020). Non-Interactive Counseling is a counseling activity that is carried out through the use of media sending messages, social media at different times. Both types of services require a repository for recording student progress. This repository will be used by the school to see the potential of students from various aspects, monitor students based on violations, and determine solutions to the results of discussions between various elements including, homeroom teachers, counseling guidance teachers, vice-principals, and school principals.

SMK Komputer Indonesia is one of the vocational high schools in the Bogor district. Counseling guidance is still carried out in a non-interactive form. Recording of student progress is still done manually using a ledger. Weaknesses in such a system are: student development data is not recorded in a structured manner. This causes all decisionmaking related to student development not based on data in the record book and there is no teacher's knowledge as a counselor. Based on the situation analysis, there are partner problems as follows:

a) Cybercounseling activities are not yet optimal. In the period before and during the pandemic, the Indonesian Computer Vocational School had used cyber counseling to guide students. Coaching is still being carried out for 
students who are reported to need treatment through counseling and still depends entirely on the activity of the teacher.

b) Recording of student progress is still done manually. Reporting on student progress carried out by the teacher is a written report submitted to the school and parents of students. Based on this report, schools can provide recommendations for further action. Records that are still done manually and separately can cause gaps between schools and students due to inappropriate reporting.

c) There are no facilities for students to be open in expressing problems, both academic and non-academic. The process that has been carried out by the Indonesian Computer Vocational School is that BK or walas teachers receive reports and direct observations and then approach students for coaching. Students still use other media to express their problems. Against negative effects if student activities in cyberspace cannot be monitored in detail. Berdasarkan permasalahan tersebut maka perlu adanya sebuah aplikas untuk penguatan kegiatan cyber counceling sekolah. SMK Komputer Indonesa Kabupaten Bogor menajadi sekolah percontohan untuk implementasi aplikasi tersebut. Tujuan kegiatan ini adalah: 1)Melakukan pengembangan aplikasi tele monitoring counceling siswa di SMK Komputer Indonesia., 2)Melakukan sosialisai dan transfer teknologi aplikasi yang dikembangan kepada pihak sekolah untuk dapat diimplementasikan dalam kegiatan counceling atau bimbingan konseling.

\section{Literature Review}

Counseling is all forms of relationship between two people, where one person, namely the client, is helped to be more able to adapt effectively to himself and his environment. The atmosphere of this counseling relationship includes the use of interviews to obtain and provide various information, train or teach, increase maturity, provide assistance through the decision-making and healing efforts (therapy) (Yusuf, 2009). Counseling is a form of helpful relationship. The meaning of assistance here is as an effort to help others so that they are able to grow in the direction they choose themselves, are able to solve the problems they face, and are able to face the crises experienced in their lives. The task of the counselor is to create the necessary conditions for the growth and development of the client (Yusuf, 2008).

Existing technological developments have affected all aspects of life, one of which is guidance and counseling services. Advances in information and communication technology have had a major influence on counseling guidance services (Hariko, 2017). Along with the times, counseling is no longer done face to face but can be done remotely using an internet network called cyber counseling (Ifdil \& Ardi, 2013).

There are three stages in the cyber counseling service process, namely: (1) The preparation stage, which includes the preparation of hardware and software used in the counseling process between counselors and counselees, (2) Stages of the guidance and counseling service process, namely providing counseling to the counselee as well as when meeting face to face. Implementation of cyber counseling using general techniques and special techniques. The implementation of cyber counseling emphasizes the completion of counseling problems, (3) The final stage, namely ending the counseling process by providing an evaluation of the success of counseling and follow-up. There are four possibilities that occur in the evaluation process, including (a) a successful counseling process is marked by the counselee's condition that meets effective daily living, (b) counseling is continued with face to face, (c) counseling services are continued in the next session, and (d) ) the counselee is referred to another counselor. (Farozin, 2020).

There are several e-counseling models including (1) video conferencing; (2) Chat, Instant Messaging, and Social Networking; (3) e-mails; (4) mobile phones; and (5) websites. There are previous studies that have been carried out related to the implementation of counseling using several media, including by Hastuti (2021). This research is a descriptive quantitative study with a survey design involving 106 school counselors as respondents. Data collection using Online Media Usage Survey Questionnaire. The results show that the Google Classroom and Google Form applications are often used as a medium for classical guidance and the WhatsApp application for individual/group counseling. Meanwhile, the conditions that underlie the selection of online media are the limitations of the internet network, the ability to use information technology of students, the financial capabilities of students, and the assurance of confidentiality, especially for counseling. From the results of this study, it can be seen that during the Covid 19 pandemic, school counselor services tend to be more asynchronous than synchronous. The results of this study can be used as the basis for research on the development of online-based guidance and counseling services

\section{Materials and Methods}

\subsection{Materials}

This activity was carried out at the SMK Komputer Indonesia, Kabupaten Bogor. The data is sourced from student data which includes: student data, discipline data, and counseling guidance data. Elements of schools involved include school leaders, BK teachers, and several teachers who become homeroom teachers for each class. The number of students who interact is a total of 205 people. 


\subsection{Methods}

Activities are carried out through three main stages, as follows:

a) Survey on counseling activities and needs of schools, parents, and students. This activity is an initial activity carried out in month 1 . The survey was carried out by distributing questionnaires to students and BK teachers regarding the implementation of cyber counseling at SMK Komputer Indonesia

b) Preparation of information systems in the form of telemonitoring for BK teachers and SMK Komputer Indonesia students. The preparation of a computer-based information system is carried out through the stages of problem identification, design, manufacture, and testing. The problem identification stage is carried out at the SMK Komputer Indonesia through interviews and observations are carried out in the second month. The design and manufacture were carried out at Universitas Pakuan for 3 months.

c) Socialization to Partners. The activity was carried out by inviting representatives of parents and students to socialize the telemonitoring application. The description of the three stages is presented in Figure 1.

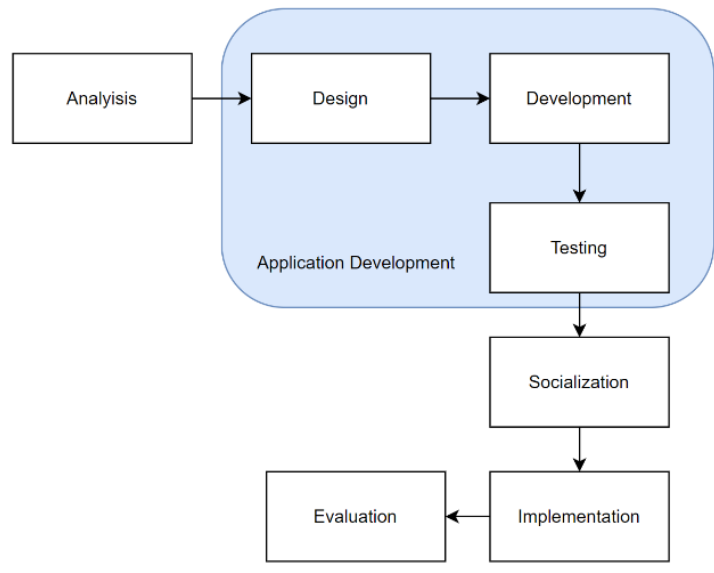

Figure 1. Stages of implementation of activities

\subsubsection{Steps of Activity}

Requirements Analysis. This stage performs an analysis of cyber counseling problems. The analysis was carried out through interviews, distributing questionnaires, and observation. The output of this stage is the availability of requirements specification documents related to the application to be developed and implementation to partners.

Application Development. One of the outcomes of this activity is the creation of a mobile application for BK teachers and Indonesian Computer Vocational School students as a means of communication in cyber counseling activities. In addition to being used as a means of communication, this application will be a repository for student coaching activities as well as student activity reporting and monitoring to the school. The stages in developing this application are as follows:

a. Perancangan. Perancangan aplikasi dilakukan dengan 3 modul, yaitu : a). perancangan database, b) perancangan GUI dan c). perancangan reporting.

b. Application creation. Applications are made using mobile programming. Applications will be provided for easy access and use based on the target user.

c. Testing. The trials carried out at this stage are functional trials, testing the level of user acceptance. The system improvement process continues to be carried out after receiving evaluations from both developers and users.

Socialization. The socialization of the application was carried out at the SMK Komputer Indonesia by inviting the school committee, teacher council, and student representatives (osis). Through this socialization activity, responses and inputs for system improvement will be obtained as well as knowing the level of partner participation in the applications provided.

Implementation. Implementation is the application of the application in Mitra. Implementation begins with completing the student and BK teacher data, and entering records of student coaching activities into the application to obtain an evaluation of the system that has been prepared. Implementation is done by involving 
the school, parents, and students. Implementation can be done in a simulation to represent the elements of the school as a whole.

Evaluation. Evaluation is carried out after 1 month of implementation activities. Based on the evaluation will be obtained the level of participation of students, parents, and teachers. Through evaluation, the development will also be obtained. Evaluation is carried out through the distribution of questionnaires as well as interviews and direct observation.

\section{Result and Discussion}

The development of computer-based applications to strengthen cyber counseling activities is carried out collaboratively between schools and courts. The initial stage is a needs analysis. Needs analysis through the stages of observation and distributing questionnaires to students and parties to obtain the urgency of counseling activities and the media that are expected to be used. The results of the needs analysis are presented in Figure 2.
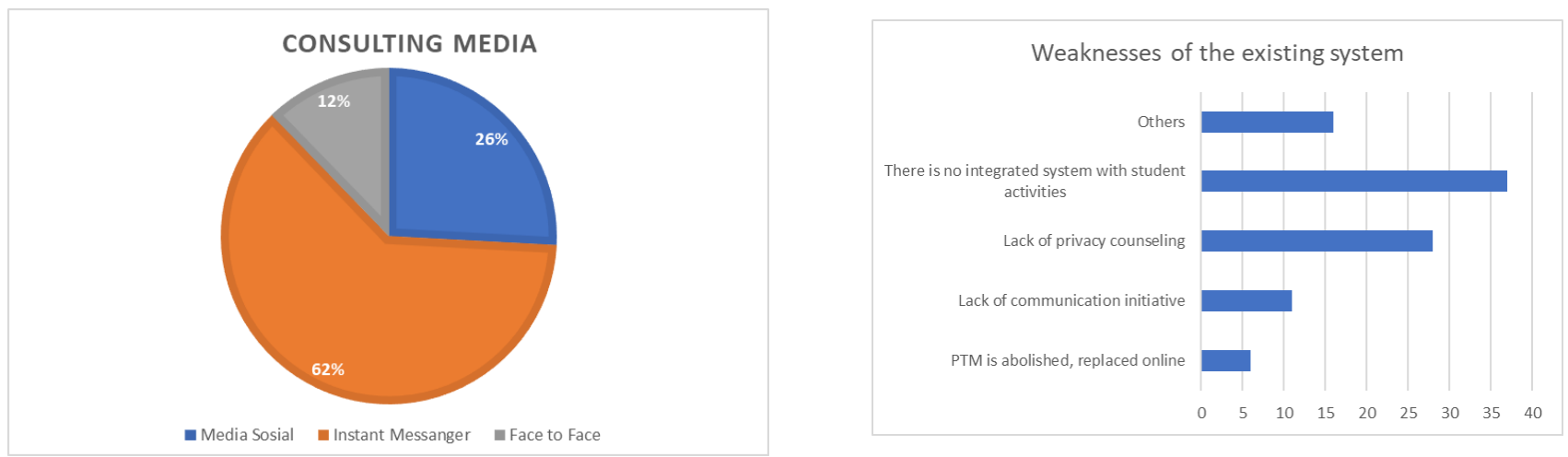

Figure 2. Questionnaire results for students and schools

Based on the results of the questionnaire analysis, $62 \%$ of students carried out counseling activities using the instant messenger application. This is especially so during the pandemic. Based on the results of in-depth interviews, students who do counseling through instant messengers are students who always actively consult with the school during offline teaching and learning activities. The matters that were consulted were as follows: 1). School, 2) Family, 3) Friendship, 3) Romance and others.

Questionnaires were also given to the school to see the school's need for the cyber counseling system to be built. Based on the analysis of the results of the questionnaire, it was found that $38 \%$ needed cyber counseling applications that were integrated with student activities and $28 \%$ needed private applications between schools and students.

Based on this, strengthening counseling activities requires computer-based applications that can collect data on student activities at school, counseling materials, discipline by paying attention to the privacy of each student. The developed system has an architecture as shown in Figure 3:

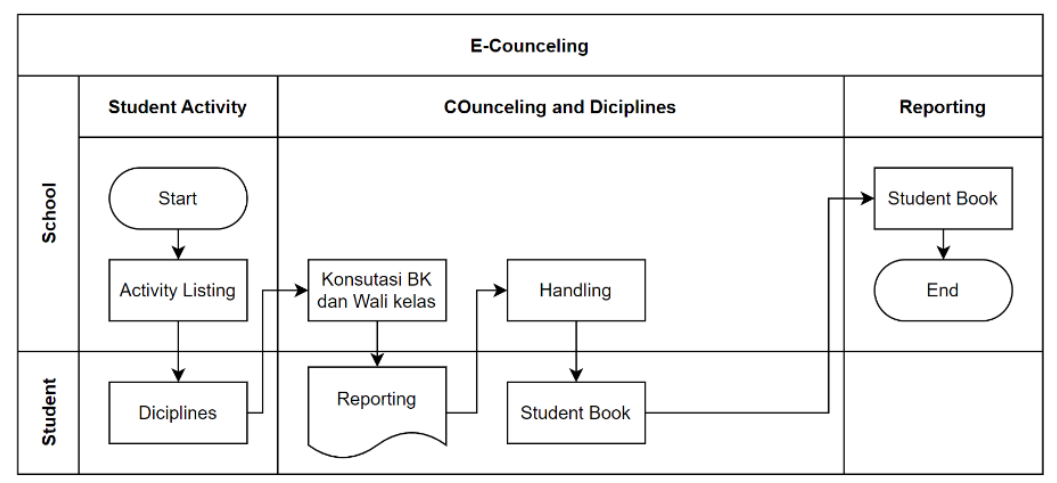

Figure 3. E-counseling architecture 
The development of the system begins with an understanding of the Standard Operating Procedure of the school in conducting counseling guidance and activities related to counseling guidance, including discipline and student achievement. Based on the results of understanding SOPs, regulations of the education office and schools, a document flow is made as the initiation stage of system design.

Based on the architecture that has been designed and the review of the document, an e-counseling application has been produced which has recorded 205 students based on a ledger containing student activities and records of student discipline. The management of the application user is divided into 3, namely: school leaders, Deputy Head of Student Affairs, BK teachers and students. Some views of the e-counseling application are presented in Figure 4.
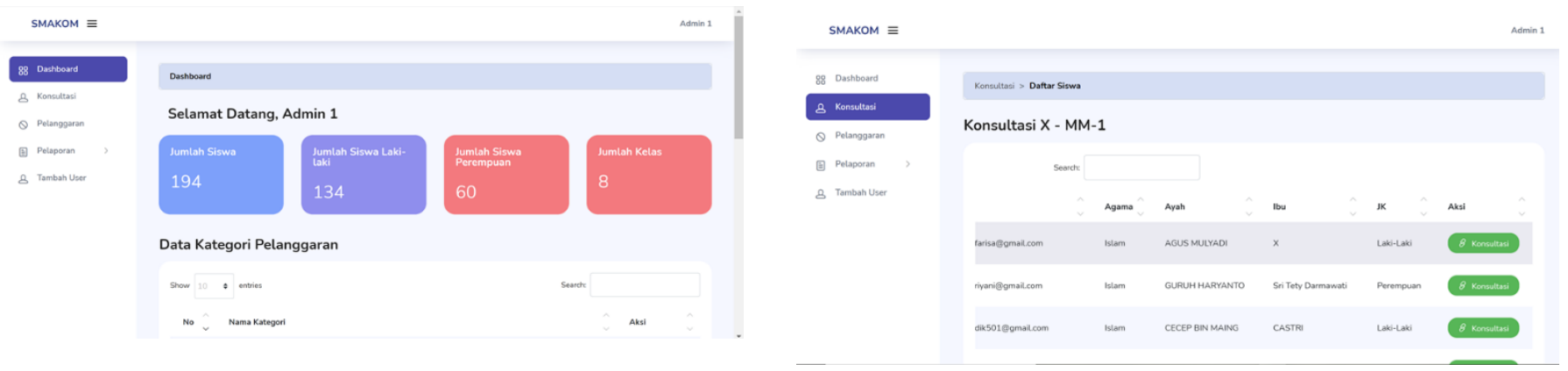

Figure 4. e-counseling application

Based on the results of the development, the e-counseling application produces software that can perform the following activities: 1) recording student activities, especially violations and disciplines that are the domain of BK teachers, 2) recording counseling activities and 3) making reports/recapitulations related to Counseling Guidance activities.

Reports or recapitulations can be used by schools to determine student handling strategies so that they can prepare students' academic quality for the better.

The e-counseling application can be a repository of student development during school at the Indonesian Computer Vocational School. This repository can be a reference for schools in making decisions related to discipline, character development, and student achievement.

Trials of the e-counseling application have been carried out through outreach activities to students and schools. The socialization was carried out to 50 students and 15 teachers. Evaluation of the application uses the User Acceptance Test tool-type Black Box testing (Mohd, 2015) and provides a summary of the evaluation results as follows:

Table 1: User Acceptance Result

\begin{tabular}{|c|c|c|c|}
\hline \multirow[t]{2}{*}{ No } & \multirow[t]{2}{*}{ Acceptance Requirements } & \multicolumn{2}{|c|}{ Test Result (Number of People) } \\
\hline & & Accept & Reject \\
\hline 1 & $\begin{array}{l}\text { The system must execute to the end of } \\
\text { the job. }\end{array}$ & 60 & 5 \\
\hline 2 & Login dan quit easily & 45 & 20 \\
\hline 3 & Students are in the appropriate class & 65 & 0 \\
\hline 4 & $\begin{array}{l}\text { Users cannot access data that is not } \\
\text { their right }\end{array}$ & 51 & 14 \\
\hline 5 & $\begin{array}{l}\text { The system is user friendly and not } \\
\text { confusing. }\end{array}$ & 63 & 2 \\
\hline 6 & $\begin{array}{l}\text { WA notifications are } \\
\text { received. }\end{array}$ & 40 & 25 \\
\hline 7 & Data is accessible on any browser. & 65 & 0 \\
\hline 8 & $\begin{array}{l}\text { The system can generate a printed } \\
\text { report }\end{array}$ & 15 & 50 \\
\hline 9 & $\begin{array}{l}\text { The system is already integrated with } \\
\text { the existing system }\end{array}$ & 0 & 65 \\
\hline 10 & Sistem memiliki privacy yang baik & 55 & 10 \\
\hline
\end{tabular}

In the implementation of this service activity, the inhibiting factors are:

a) There are still unequal understandings between school elements related to the implementation of SOPs and regulations that have been set by schools. This is one of the factors of difficulty in the development

b) Consistency in the application of e-counseling on the part of students and schools. Problems with technology gaps and habitual factors make this application software whose reliability is still in doubt. 
c) Data related to previous counseling and guidance activities were separate, not integrated and incomplete (some data were in the form of hardcopy or other software (GIBAS).

\section{Conclusions}

Cybercounseling activities have been carried out by the Indonesian Computer Vocational School through monitoring social media owned by students and through messaging applications with a special approach. This activity is still not optimal because the accessibility of students to social media and messaging applications is not the same. Therefore, to strengthen cyber counseling activities, use applications that are easy, simple, and have good connectivity between teachers and students. Data repository related to counseling guidance provides better access to data. The visible results of this activity are: an e-counseling application and a computer-based repository system are available. The ecounseling application has gone through the User Acceptance Test stages as users are: students, picket teachers, BK teachers, homeroom teachers, and principals. The user acceptance rate is $85 \%$. This shows that there are several aspects that must be improved, including the flexibility of adding problem criteria. Based on the results of the socialization that has been carried out, e-counseling applications and repositories have now been used in the process of migrating existing counseling guidance data into the computer system.

\section{Acknowledgments}

Financial support for this research was provided by a grant from the research institute and community services Universitas Pakuan.

\section{References}

Arista, D. A. dkk. (2017). Aplikasi Cyco (Cybercounseling) Sebagai Salah Satu Alternatif Model Konseling di Sekolah. Seminar Nasional BK FIP-UPGRIS. 230-238

Farozin, M., Kurniawan, L., \& Irani, L. C. (2020). The Role of Guidance and Counseling in Character Education. Proceedings of the 2nd International Seminar on Guidance and Counseling 2019 (ISGC 2019), 462, 112-116. https://doi.org/10.2991/assehr.k.200814.025

Gumilang, G. S. (2020). Guidance and Counseling Service During Covid-19 Pandemic (Analytical Study of Lakon Marifat Dewa Ruci). International Reseacrh Journal of Multidiciplinary Studies, 6(8), 1-11.

Hariko, R. (2017). Landasan Filosofis Keterampilan Komunikasi Konseling. Jurnal Kajian Bimbingan Dan Konseling,2(2),41-49.

Ifdil, I., \& Ardi, Z. (2013). Konseling Online Sebagai Salah Satu Bentuk Pelayanan E-konseling. Jurnal Konseling Dan Pendidikan, $1,15-21$

Hastuti, M. M. S \& Tyas, P. H. P. (2021). Online Media Usage in Guidance and Counseling Services during the Covid-19 Pandemic. Jurnal Kajian Bimbingan dan Konseling, 6(2), 60-70. https://doi.org/10.17977/um001v6i22021p060-070

Kraus, R. et al. (2011). A Handbook for Mental Health Professionals. India: Elsevier Inc

Mohd, C. K. N. C. K., \& Shahbodin, F. (2015). Personalized learning environment: alpha testing, beta testing \& user acceptance test. Procedia-Social and Behavioral Sciences, 195, 837-843.

Shaw, H. E., \& Shaw, S. F. (2006). Critical Ethical Issues in Online Counseling: Assessing Current Practices With an Ethical Intent Checklist. Journal of Counseling \& Development, 84(1), 41-53. https://doi.org/10.1002/j.1556- 6678.2006.tb00378.

Yusuf, S. (2009). Program Bimbingan dan Konseling Di Sekolah. Bandung: Rizqi Press

Yusuf, S dan Nurihsan, J. (2008). Landasan Bimbingan dan Konseling. Bandung: PT. Remaja Rosdakarya 